\title{
PETROGRAPHICAL AND PETROCHEMICAL FEATURES OF THE ESTONIAN PRECAMBRIAN PORPHYRACEOUS POTASSIUM GRANITES
}

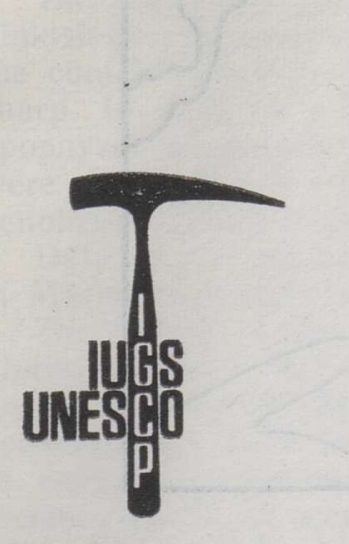

Project 275

BALTIC SHIELD and

Project 315

RAPAKIVI GRANITES

\begin{abstract}
Estonian porphyraceous potassium granites of rapakivi age are coarse- to medium-grained, pinkish-grey rocks with microcline porphyroblasts. Five small plutons of these granites - Märjamaa, Neeme, Ereda, Naissaare, and Taebla - sharply transect the surrounding rocks. These granites as well as the veins of aplites cutting them contain microcline, quartz, plagioclase, and biotite as principal minerals and apatite, fluorite, zircon, sphene, orthite, muscovite, and rutile as accessory minerals; hornblende is common in melanocratic granites; the main opaque minerals are magnetite and ilmenite. By their chemical composition, Estonian porphyraceous granites can be assigned to the rapakivi granite formation. Estonian porphyraceous granites have relatively low Niggli $m g$-indices $(0.1-0.35)$ and negative $t$ value; the value of alk is systematically lower than that of the rapakivi granites. On the basis of different $\mathrm{Mg} / \mathrm{Mg}+\mathrm{Fe}$ and $\mathrm{Ca} / \mathrm{Ca}+\mathrm{Na}$ ratios, three separate trends, possibly corresponding to different phases, can be distinguished. The age of these granites varies from $1.62-1.69 \mathrm{Ga}$ (K-Ar, biotite), $\mathrm{U}-\mathrm{Pb}$ age show $1.66 \mathrm{Ga}$ and $\mathrm{Rb}-\mathrm{Sr}-1.71 \mathrm{Ga}$. On the basis of the mineralogical and chemical composition, different subtypes (possible phases) of granites are described.
\end{abstract}

\section{Introduction}

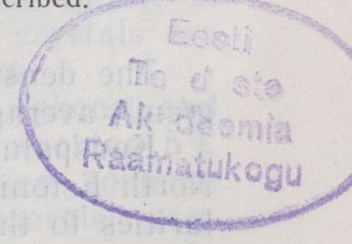

The present paper gives a descriptive review of the general petrographical (M. Niin) and petrochemical (A. Soesoo) features of the Estonian porphyraceous granites, being an introduction to subsequent detailed investigations.

In Estonia, five small plutons of porphyraceous granites - Märjamaa, Neeme, Ereda, Naissaare, and Taebla - are known (Fig. 1). Possibly, the oval-shaped northwestern part of the Märjamaa pluton can be considered as an individual pluton. According to the geophysical data, these plutons occur as intrusions sharply transecting the surrounding rocks. This is also confirmed by two drill cores through the Märjamaa and Taebla plutons. In the regional geophysical fields, the porphyraceous granites can be distinguished by negative gravity and magnetic fields (Побул, 1962).

\footnotetext{
* Eesti Teaduste Akadeemia Geoloogia Instituut (Institute of Geology, Estonian Academy of Sciences). Estonia pst. 7, EE0105 Tallinn. Estonia. ** Eesti Geoloogiakeskus (Geological Survey of Estonia). Pikk 67, EE0101 Tallinn.
} 


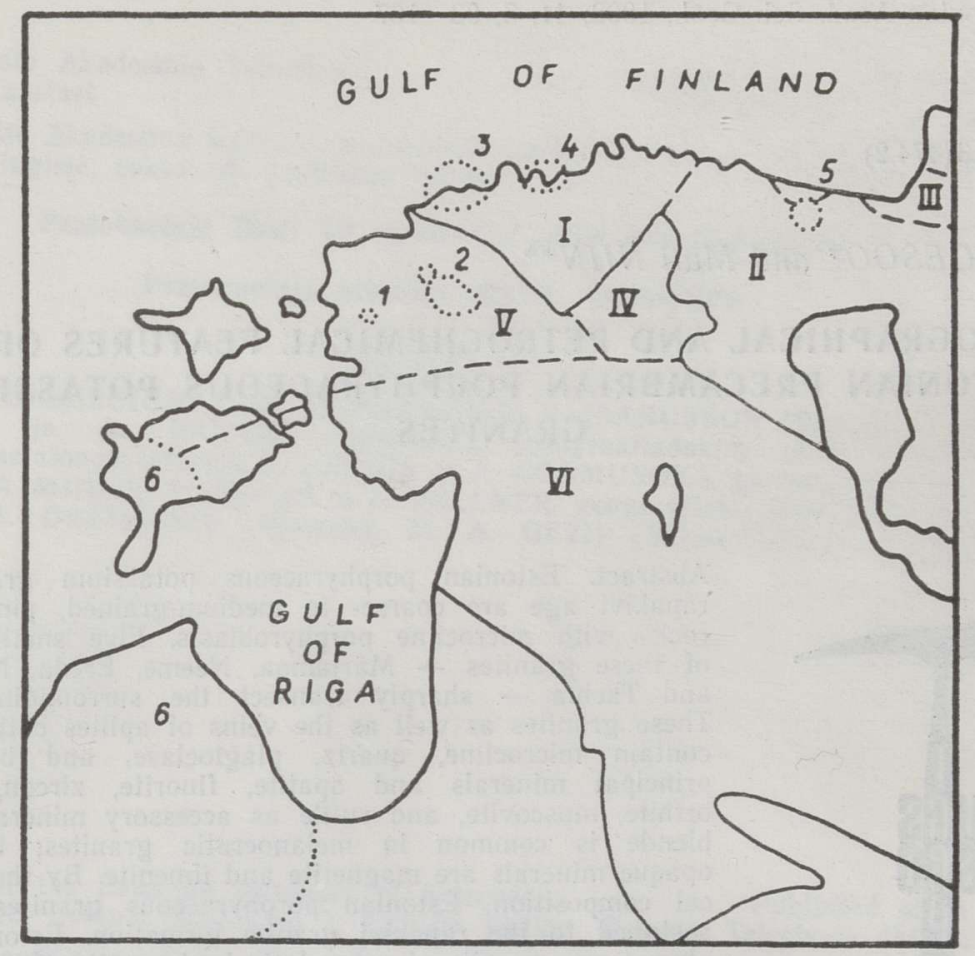

Fig. 1. Location of plutons of the porphyraceous potassium granites and zonation of the Estonian basement. 1 - Taebla, 2 - Märjamaa, 3 - Naissaare, 4 - Neeme, 5 Ereda, 6 - Riga pluton of rapakivi granites. I - Tallinn, II - Alutaguse, III - Jõhvi zones; IV - Tapa, V - West-Estonian, and VI - South-Estonian blocks.

The density of the above-mentioned rocks ranges from 2.57 to 2.81 $\mathrm{g} / \mathrm{cm}^{3}$, averaging $2.63 \mathrm{~g} / \mathrm{cm}^{3}$ (Побул et al., 1968).

Kuuspalu (Кууспалу, 1975) compared the porphyraceous granites of North Estonia with the granites of South Finland, describing their similarities to the third-group granites by Sederholm (Эскола, 1967) and showing that these granites belong to the rapakivi granite formation.

The age of the Estonian porphyraceous granites ranges from 1.62 to $1.69 \mathrm{Ga}(\mathrm{K}-\mathrm{Ar}$, biotite), or $1.66 \mathrm{Ga}$ by $\mathrm{U}-\mathrm{Pb}$ and $1.71 \mathrm{Ga}$ by $\mathrm{Rb}-\mathrm{Sr}$ estimations (Пуура, 1974; Пуура et al., 1974; Пуура et al., 1983). Three zircon fractions from the first phase of the Märjamaa pluton provide an upper intercept age of $1.626 \mathrm{Ga}$ (Kirs et al., 1991). By the isotopic age, the Estonian porphyraceous granites are comparable with some Finnish intrusions such as Wiborg, Suomenniemi, Ahvenisto, Onas, Bodom, Obbnäs of 1.62-1.65 Ga age (Rämö, 1991; Vaasjoki, 1977) and Dala granites - 1.67 Ga old (Lundqvist, 1968; Welin and Lundqvist, 1970).

\section{Materials and Methods}

Altogether, 61 drill holes of five Estonian small plutons - Neeme (35 cores), Naissaare (7), Märjamaa (15), Taebla (2), and Ereda (2) - have been studied. Petrographical descriptions of the Estonian porphyraceous granites are based on the earlier field works and thin 
section studies. Ninety-eight wet chemical analyses of these rocks and their aplites (made in the laboratory of the Geological Survey of Estonia; Table 1) were used for general petrochemical description. $\mathrm{K}-\mathrm{Na}-\mathrm{Ca}-\mathrm{Si}$ ratio, $\mathrm{Ca} / \mathrm{Ca}+\mathrm{Na}, \mathrm{Mg} / \mathrm{Mg}+\mathrm{Fe}$ ratios and $\mathrm{Niggli}$ main values were used as characteristics reflecting the general petrochemical features of the porphyraceous granites and for their comparison with typical rapakivi granites.

\section{Petrography}

The Märjamaa pluton $(40 \times 25 \mathrm{~km})$ is composed of coarse-grained, pinkish-grey porphyraceous granite. According to the geophysical data, the contacts between the granites and the surrounding gneisses are sharp. In drill core No. 314, contact alteration was absent but some apophyses of porphyraceous granites within the surrounding gneisses were observed. The rocks of the central part of the pluton contain gneiss xenoliths with the diameter up to $20 \mathrm{~cm}$.

Data on the mineralogical composition of 25 analysed thin sections of Märjamaa porphyraceous granites are presented in Table 2.

The quartz of the porphyraceous granites of the Estonian small plutons shows often weak undulatory extinction. Two generations of quartz have been distinguished. The first generation occurs partly between the potash feldspar individuals as anhedral crystals and partly as euhedral inclusions within the potash feldspar (microcline). The second generation occurs as anhedral crystals in the groundmass. Potash feldspar (microcline) is present as phenocryst (diameter $2-3 \mathrm{~cm}$ ) and in the groundmass. The mineral is often perthitic. The phenocryst contains inclusions of quartz, biotite, and rare sphene. The plagioclase forming euhedral tabular or prismatic crystals is represented by oligoclase-andesine. In places, the observed plagioclase shows a zone of andesine in the central part of the crystal and a zone of oligoclase at the margins. Twinning according to the albite law is common. Biotite is pleochroic in light yellow to brown colours. Its anhedral crystals are often clustered together as swarms of small or large flakes.

Among the accessory minerals, apatite, fluorite, zircon, sphene, and orthite are present, with the content of sphene and zircon reaching. $5 \%$ and $3 \%$, respectively. Hornblende occurs sporadically, being common in drill cores 314 and 302 . The content of main opaque minerals, magnetite and ilmenite, may reach $3 \%$.

The central part, the most melanocratic and basic type of porphyraceous granites within the Märjamaa pluton, is interpreted as the first intrusive phase. The second intrusive phase is represented by muscovite-bearing granites containing biotite. The granites of the third phase are of more leucocratic composition and in places of trachytoid texture.

The density groups of Märjamaa granites correspond to the phases distinguished on the basis of petrographical data. The density of the rocks forming the first phase is $2.71 \mathrm{~g} / \mathrm{cm}^{3}$, that of the second phase $2.66 \mathrm{~g} / \mathrm{cm}^{3}$ (similar to the Ereda granites), the third phase $-2.63 \mathrm{~g} / \mathrm{cm}^{3}$, and the fourth phase $-2.59 \mathrm{~g} / \mathrm{cm}^{3}$; the density of aplites is $2.60 \mathrm{~g} / \mathrm{cm}^{3}$.

The Neeme pluton with the diameter of about $25 \mathrm{~km}$ and with its northern part under the Gulf of Finland, is composed of coarse- and medium-grained, pinkish-gray porphyraceous granites. In places, e. g. drill cores $507,513,521,524$, the rocks are very leucocratic with a pegmatitic structure (location of drill holes see Klein et al., in prep.). By the chemical and mineralogical composition, the rocks form two groups, 


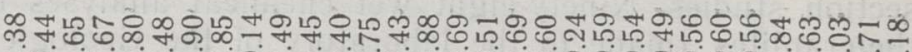

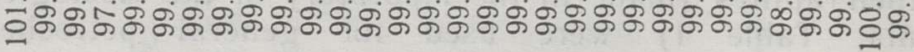

싱ㄷำ तió0000000000000000000000000000

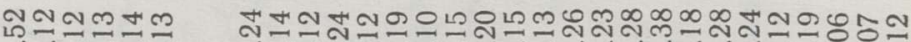

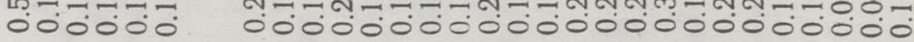

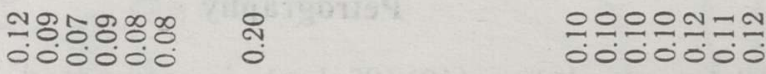

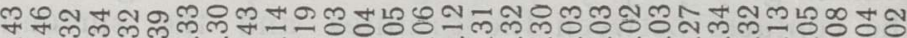
0000000000000000000000000000000

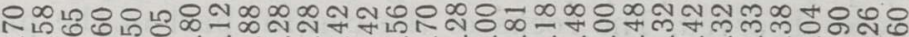

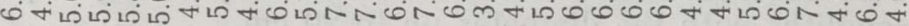

ํㅐㅇㅠ

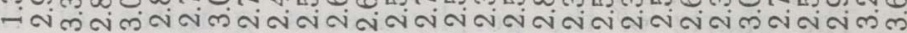

ణొన 3

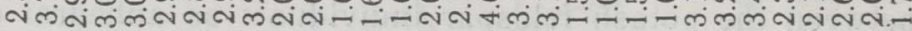

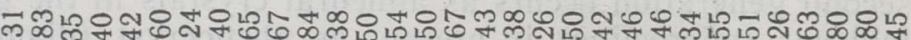
i-1-1-1-10000000-100000 $\infty$

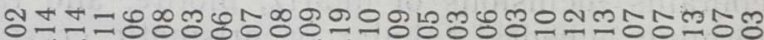

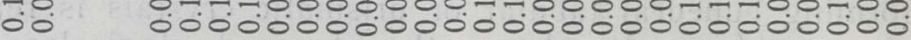

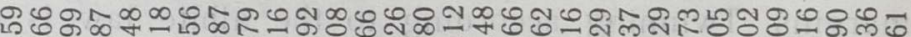

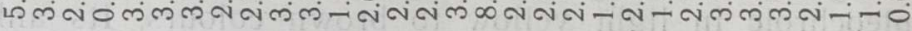

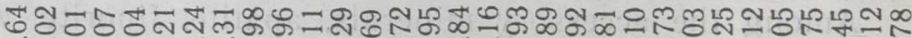

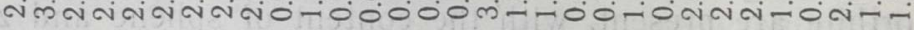

సஸำฒ

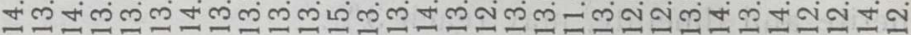

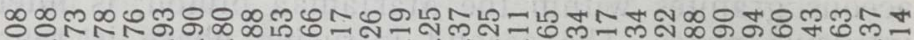
-í0000000000000-100000000000000

๒ พิ์

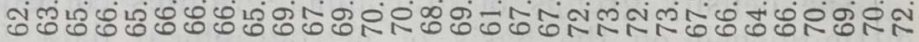

뉴유으

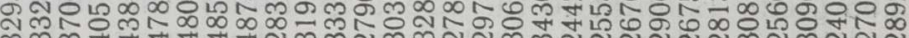
అొమ

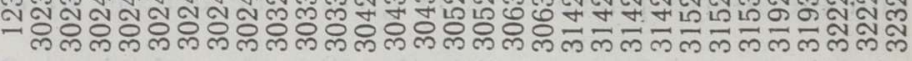

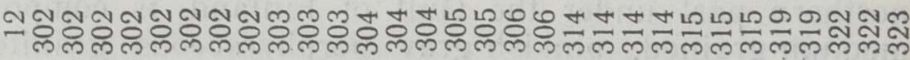

- 


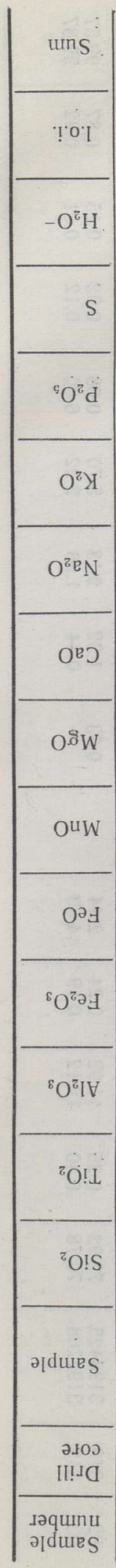

எ๐ கं

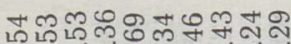
$00000000-1$

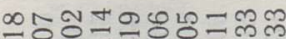
000000000

$\begin{array}{lll}0 & 8=\infty & 0 \% \\ 0 & 000 & 00\end{array}$

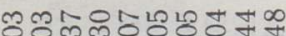
00000000

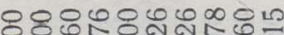
อง

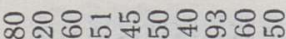

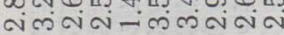

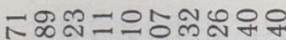
-

๓ำ $00-0000-1-1$

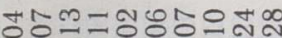
000000000

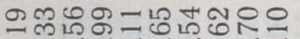
- -

유ำ 0.-0-..

ลักลำณ กำำตำ

노 000000000

ํํㅇํำ Aกษ

\section{궁요느으응ㅇㅇ}

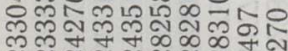
กิ

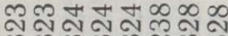

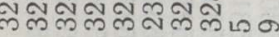

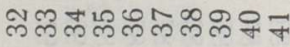

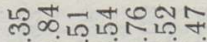

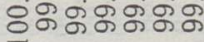

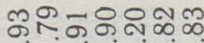
000000

$0000 \div$

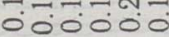

능ํㅇำำำ 0000000

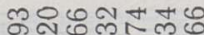

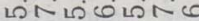

ํํㅇ눈ํํ응요

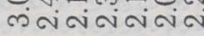

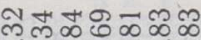
- - i i

$\infty$ t10 $\infty 00 \%$ 0000000

\section{ப} - 00000

은ํํํํำ oi-i-i-aio

ஐํํㅇํํㅉㅀำ o-i-oon-

ㄱํ은 ตี่งกำำ

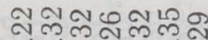
000000

₹ พำกำำㅇำ

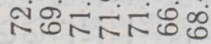

ㄴำ $⿻$

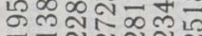

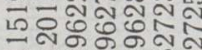

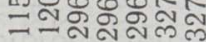

느ํํำริำ

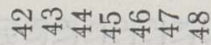

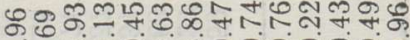
๓

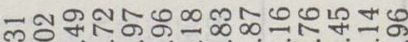
m.0000

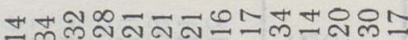
-0.00000000000

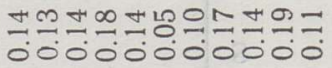

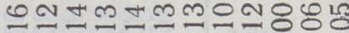
000000000000

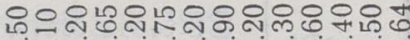
เ

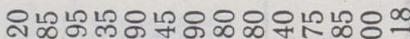

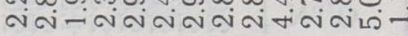

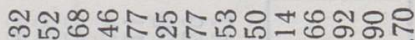

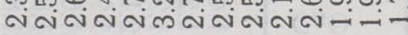

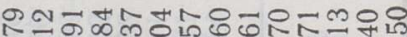
i.jo0000000-100

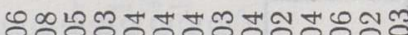
ó000000000000

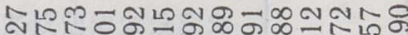
a ainia-i-i-ió-io

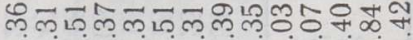

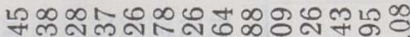
ง

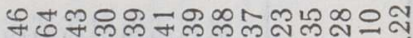
000000000000

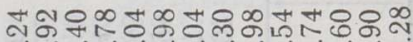
o o. on

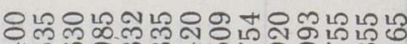

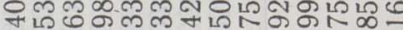

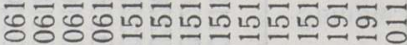

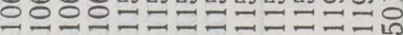

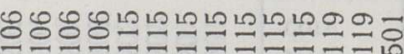

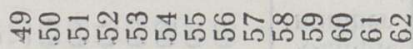




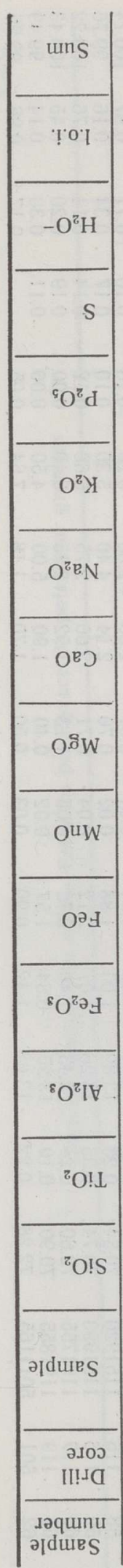

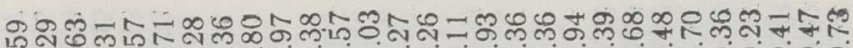

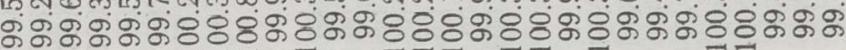

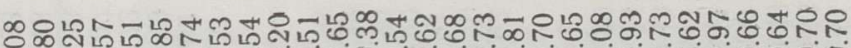

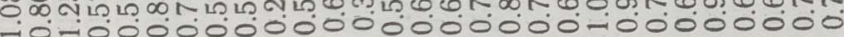

ஸे

00

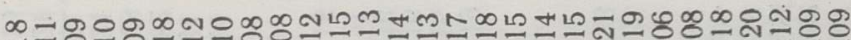

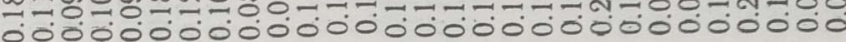

능 0

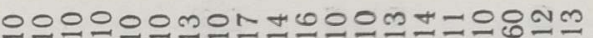

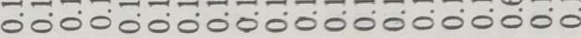

잉으

00

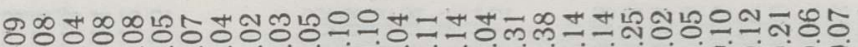

88 00000000000000000000000000000

0ं0

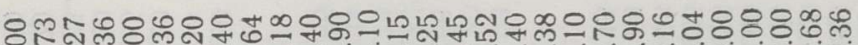

RN

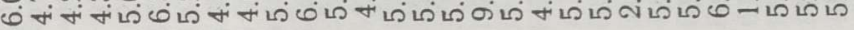

เอ

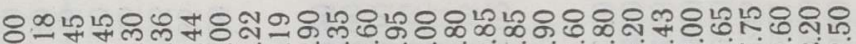

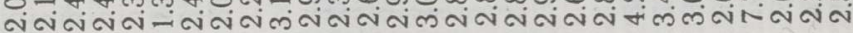

$\infty \infty$

oi

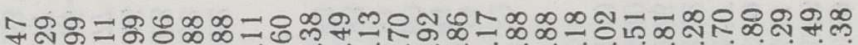
लैฺ $-\dot{0}$

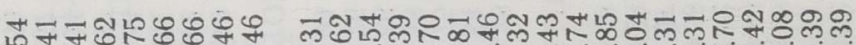
00000000 0000000-100-10000-00

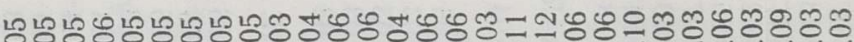

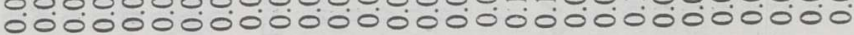

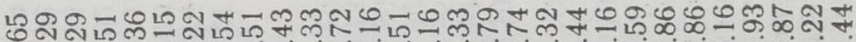

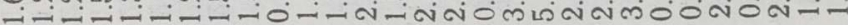

rif

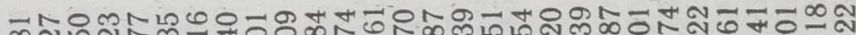

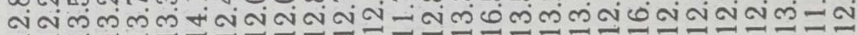

ต้ำ ¿ำ

ํㅕำผ 0000000000000000000000000000

노융 00

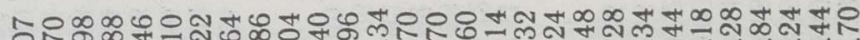
and

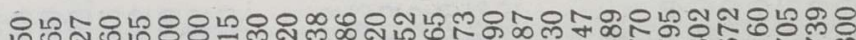

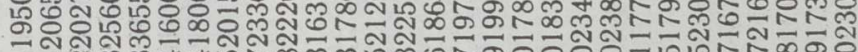
顽

$\bar{m} \bar{c}$

-

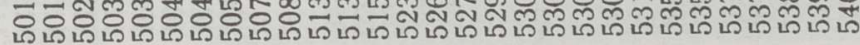




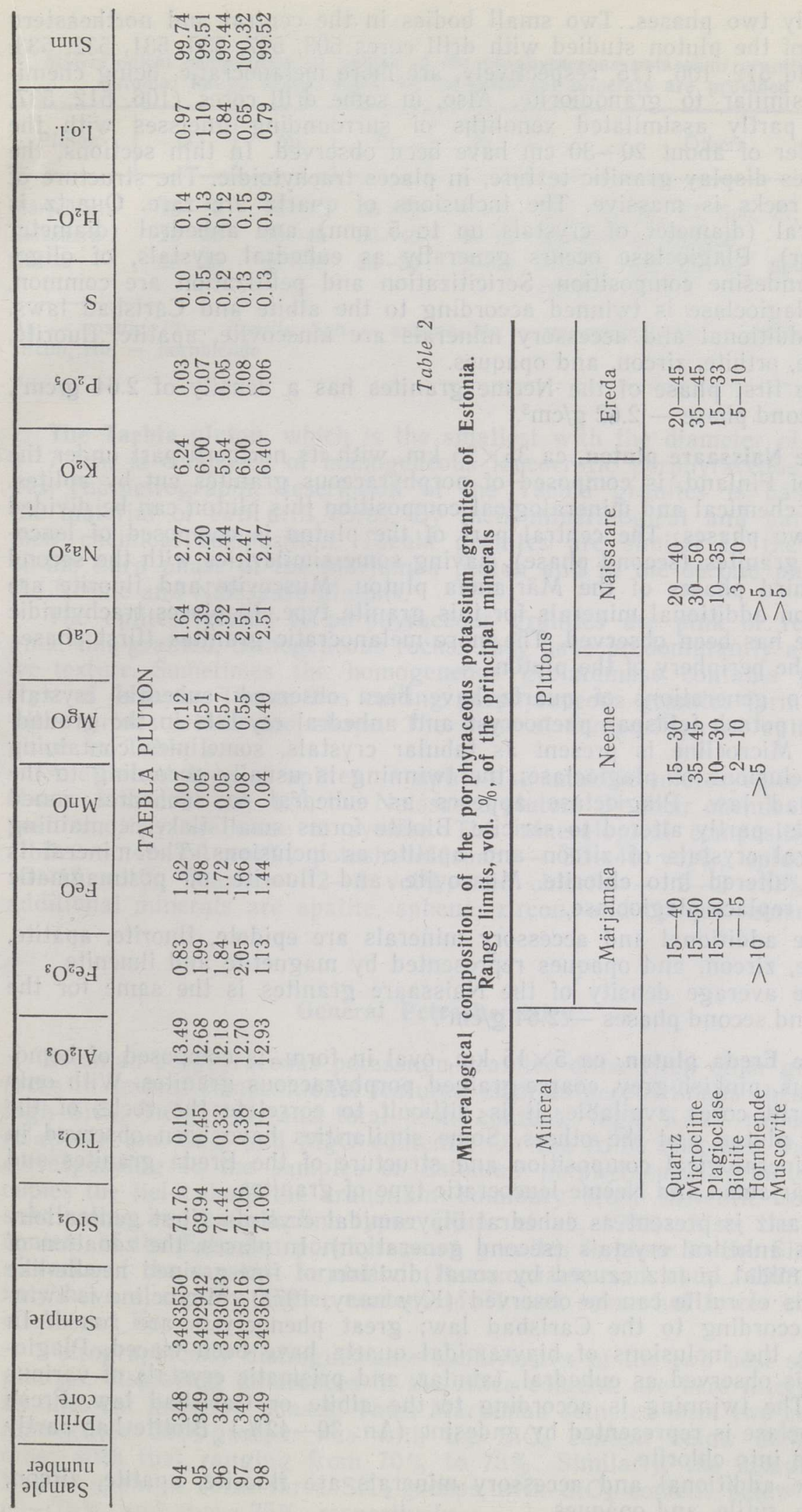


possibly two phases. Two small bodies in the central and northeastern parts of the pluton studied with drill cores $503,527,530,531,532,533$, 538 and $512,106,115$, respectively, are more melanocratic, being chemically similar to granodiorite. Also, in some drill-cores $(106,512,537$, 538), partly assimilated xenoliths of surrounding gneisses with the diameter of about $20-30 \mathrm{~cm}$ have been observed. In thin sections, the granites display granitic texture, in places trachytoidic. The structure of these rocks is massive. The inclusions of quartz are rare. Quartz is euhedral (diameter of crystals up to $5 \mathrm{~mm}$ ) and anhedral (diameter smaller). Plagioclase occurs generally as euhedral crystals, of oligoclase-andesine composition. Sericitization and pelitization are common. The plagioclase is twinned according to the albite and Carlsbad laws. The additional and accessory minerals are muscovite, apatite, fluorite, sphene, orthite, zircon, and opaques.

The first phase of the Neeme granites has a density of $2.64 \mathrm{~g} / \mathrm{cm}^{3}$, the second phase $-2.62 \mathrm{~g} / \mathrm{cm}^{3}$.

The Naissaare pluton, ca $35 \times 25 \mathrm{~km}$, with its northern part under the Gulf of Finland, is composed of porphyraceous granites cut by aplites. By its chemical and mineralogical composition this pluton can be divided into two phases. The central part of the pluton is composed of leucocratic granites (second phase), having some similarities with the second and third phases of the Märjamaa pluton. Muscovite and fluorite are common additional minerals for this granite type. In places trachytoidic texture has been observed. The more melanocratic granites (first phase) form the periphery of the pluton.

Two generations of quartz have been observed: euhedral crystals within potash feldspar phenocryst and anhedral crystals in the groundmass. Microcline is present as tabular crystals, sometimes containing the inclusions of plagioclase; the twinning is usually according to the Carlsbad law. Plagioclase appears as euhedral to subhedral zoned crystals, partly altered to sericite. Biotite forms small flakes containing euhedral crystals of zircon and apatite as inclusions. The mineral is partly altered into chlorite. Muscovite and fluorite of postmagmatic origin replace plagioclase.

The additional and accessory minerals are epidote, fluorite, apatite, sphene, zircon, and opaques represented by magnetite and ilmenite.

The average density of the Naissaare granites is the same for the first and second phases - $2.64 \mathrm{~g} / \mathrm{cm}^{3}$.

The Ereda pluton, ca $5 \times 15 \mathrm{~km}$, oval in form, is composed of homogeneous, pinkish-grey, coarse-grained porphyraceous granites. With only two drill cores available, it is difficult to correlate the rocks of the Ereda pluton and the others. Some similarities have been observed in the mineralogical composition and structure of the Ereda granites and the Märjamaa and Neeme leucocratic type of granites.

Quartz is present as euhedral bipyramidal crystals (first generation) and as anhedral crystals (second generation). In places, the zonation of bipyramidal quartz caused by zonal division of fine-grained needle-like crystals of rutile can be observed (Кууспалу, 1971). Microcline is twinned according to the Carlsbad law; great phenocrysts are zoned. In places, the inclusions of bipyramidal quartz have been traced. Plagioclase is observed as euhedral, tabular, and prismatic crystals of various size. The twinning is according to the albite or Carlsbad law. Fresh plagioclase is represented by andesine (An: $30-42 \%$ ). Biotite has partly altered into chlorite.

The additional and accessory minerals are fluorite, apatite, zircon, orthite, rutile, and opaques. 
Mineralogical composition of aplites of the porphyraceous potassium granites of Estonia. Range limits, vol\%, of the principal minerals are provided

\begin{tabular}{l|c|c|c|c|c|}
\hline \multicolumn{1}{c|}{ Pluton } & Q & Mi & Pl & Bt & \multicolumn{1}{c}{ Others } \\
\hline Märjamaa & $25-35$ & $20-40$ & $25-50$ & $1-10$ & $\mathrm{Hbl}, \mathrm{Ms}, \mathrm{Ap}, \mathrm{Fl}, \mathrm{Sph}, \mathrm{Zr}$, opaque \\
Naissaare & $20-30$ & $30-40$ & $30-40$ & $5-15$ & $\mathrm{Ap}, \mathrm{Sph}, \mathrm{Zr}$, opaque \\
Neeme & $30-35$ & $35-40$ & $25-30$ & $3-10$ & $\begin{array}{l}\text { Ms }<1, \mathrm{Ap}, \mathrm{Fl}, \mathrm{Zr}, \mathrm{Sph}, \text { Orth, } \\
\text { opaque }\end{array}$
\end{tabular}

Ap - apatite, Fl - fluorite, Sph - sphene, Ms - muscovite, Orth - orthite, $\mathrm{Zr}$ zircon, $\mathrm{Hbl}$ - hornblende

The Taebla pluton, which is the smallest with the diameter of about $6-7 \mathrm{~km}$, is composed of homogeneous leucocratic porphyraceous granites. The petrographic description of the Taebla granites is based on the material of two drill cores. By their mineralogical and partly by their chemical composition, Taebla granites are similar to the rocks of the third phase of the Märjamaa pluton and to the second phase of the Neeme and Naissaare plutons.

The aplites related to porphyraceous granites are pink or reddishpink, fine-grained, homogeneous rocks. They have predominantly a massive texture. Sometimes the homogeneous groundmass contains phenocryst of feldspar. The aplites cutting porphyraceous granites form veins with various width and shape. The mineral composition of aplites is given in Table 3 .

A different type of aplites - aplite-like unakitic microsyenite - is observed in drill core 120 , the Naissaare pluton. By their chemical composition, they are close to syenite. The mineralogical composition is: albite - 40-50 vol $\%$, potash feldspar - 30-40 vol $\%$, epidote $10-15$ vol $\%$, quartz $-2-3$ vol $\%$, and chlorite - $2-3$ vol $\%$. The additional minerals are apatite, sphene, zircon, and opaque minerals.

\section{General Petrochemistry}

Estonian porphyraceous potassium granites differ from other granitic rocks in several compositional features, such as peraluminous chemistry, high $\mathrm{SiO}_{2}, \mathrm{TiO}_{2}, \mathrm{~K}_{2} \mathrm{O}$, and total iron content, high $\mathrm{K} / \mathrm{Na}$ ratio, and relatively low $\mathrm{CaO}$ and $\mathrm{MgO}$ contents. On the AFM diagram, the plot corresponding to the samples of Estonian porphyraceous granites occupies the field along the transition boundary from tholeiitic rock to subalkaline and calcalkaline types (Қирс et al., 1990). Also, the silica content of the Estonian porphyraceous granites is close to the Si-range of rocks of the rapakivi formation (Великославинский et al., 1978), but they have a slightly higher content of $\mathrm{Ti}$ and somewhat lower content of $\mathrm{Al}$ and Fe.

Petrographically distinguishable subdivisions of the two best studied plutons, displaying differences in the silica content, are here interpreted as different intrusive phases. Thus, Märjamaa samples form two equally represented $\mathrm{SiO}_{2}$-groups: one with the $\mathrm{SiO}_{2}$ content below $68 \%$, the other with that ranging from $70 \%$ to $73 \%$. Similarly, the samples of Neeme granites form three $\mathrm{SiO}_{2}$-groups with $\mathrm{SiO}_{2}$ content below $67 \%$, $69-73 \%$, and above $75 \%$, respectively. 
The average of the Niggli mean values of Estonian porphyraceous potassium granites and the Niggli average rapakivi magma (Vorma, 1976)

\begin{tabular}{l|c|c|c|c|c}
\hline \multicolumn{1}{c|}{ Pluton } & al & $f m$ & $c$ & alk & si \\
\hline Taebla & 38.7 & 16.7 & 12.5 & 32.1 & 364 \\
Neeme & 40.2 & 17.0 & 11.1 & 31.7 & 376 \\
Naissaare & 39.7 & 18.9 & 10.2 & 31.2 & 350 \\
Märjamaa & 36.6 & 22.1 & 12.0 & 29.4 & 322 \\
Ereda & 41.7 & 20.5 & 8.5 & 29.3 & 415 \\
Average of & & & & & 366 \\
plutons & 39.4 & 19.0 & 10.9 & 30.7 & 3 \\
\hline
\end{tabular}

Rapakivi magma type

$\begin{array}{llll}40 & 18 & 9 & 33 \\ 41 & 18 & 9 & 32\end{array}$

(A)

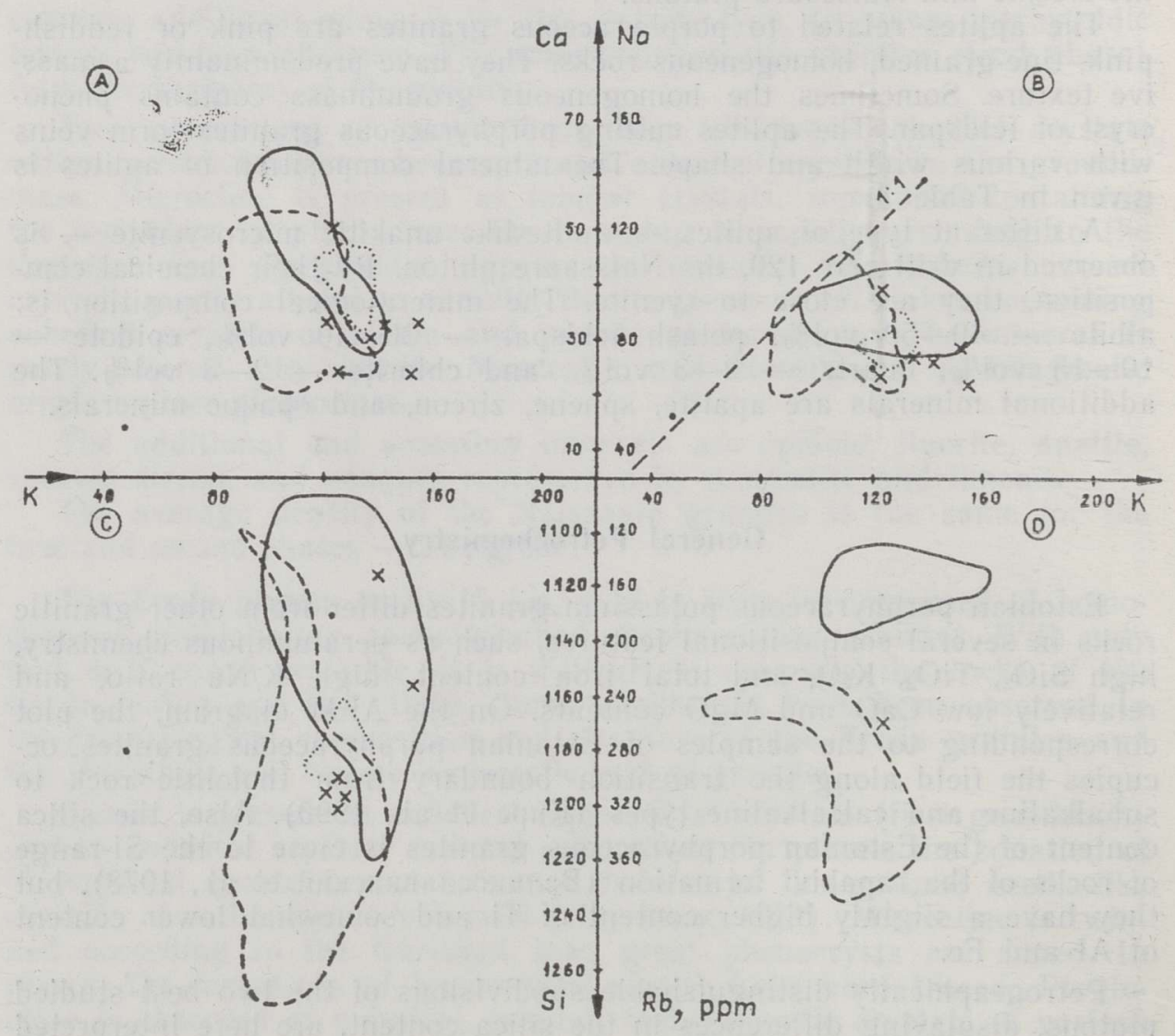

33

32
380 After Niggli, 1923

350 After Niggli, 1936 (cited in Vorma, 1976)

Fig. 2. Relationship between the atomic amount of $\mathrm{Ca}$ and $\mathrm{K}(A)$, $\mathrm{Na}$ and $\mathrm{K}(B)$, $\mathrm{K}$ and $\mathrm{Si}(C)$, and $\mathrm{K}$ and $\mathrm{Rb}(D)$ of the porphyraceous granites of Estonia. Solid line surrounds Märjamaa, broken line Neeme, and dotted line Taebla granites; dots and inclined crosses correspond to the Ereda and Naissaare granites, respectively. 

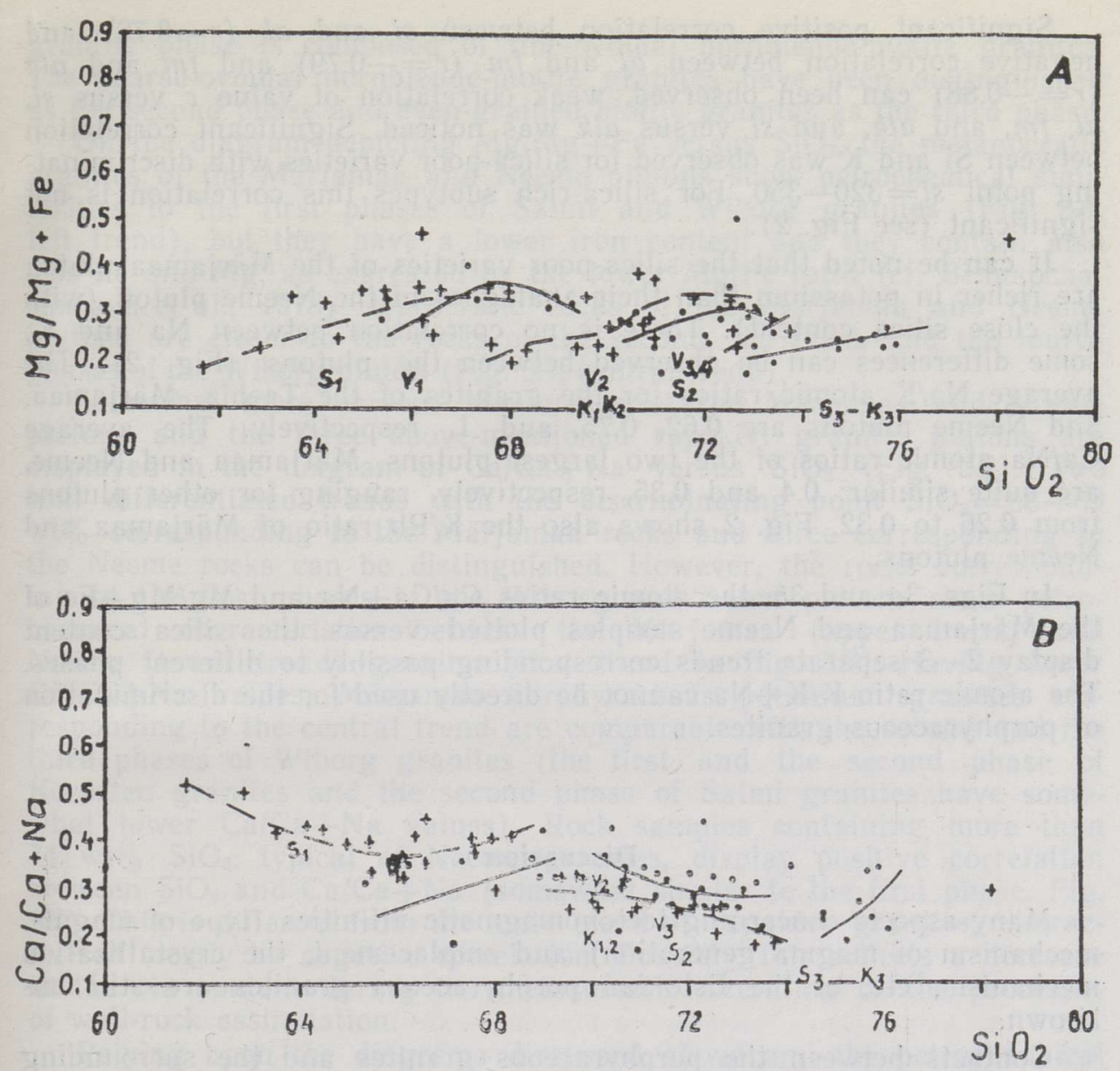

Fig. 3. Plots of the atomic ratios $\mathrm{Mg} / \mathrm{Mg}+\mathrm{Fe}$ versus wt $\% \mathrm{SiO}_{2}(A)$ and $\mathrm{Ca} / \mathrm{Ca}+\mathrm{Na}$ versus $\mathrm{SiO}_{2}(B)$ of the porphyraceous granites of Märjamaa (crosses) and Neeme (dots) plutons. Broken and solid lines display the main trends of Märjamaa and Neeme granites, respectively. $\mathrm{S}_{1}-\mathrm{S}_{3}, \mathrm{~V}_{1}-\mathrm{V}_{4}$, and $\mathrm{K}_{1}-\mathrm{K}_{3}$ correspond to the averages of the different phases of the Salmi, Wiborg, and Korosten rapakivi granite plutons, respectively.

The mean $\mathrm{Na}_{2} \mathrm{O} / \mathrm{K}_{2} \mathrm{O}$ ratio is different: Naissaare granites have the lowest ratio -0.37 , while the highest $\mathrm{Na}_{2} \mathrm{O} / \mathrm{K}_{2} \mathrm{O}$ ratio, 0.7 , characterizes the granites of the Neeme pluton. $\mathrm{Na}_{2} \mathrm{O}$ content varies from $2.5 \%$ to $3 \%$, being close to the rapakivi granites.

For all the five plutons studied, the correlation between $\mathrm{Si}$ and $\mathrm{Ti}$ is weakly negative both for the silica-poor varieties $\left(\mathrm{SiO}_{2}<69-70 \%\right)$ and the silica-rich granites. With a strong negative correlation between $\mathrm{Si}$ and $\mathrm{Ti}$, two separate trends have been observed in the Si range 71.0 $72.5 \%$. Silica-poor (up to $70 \%$ ) Neeme granites have ca $0.6 \% \quad \mathrm{TiO}_{2}$, whereas the Märjamaa granites contain $0.7-0.9 \% \quad \mathrm{TiO}_{2}$; the mean $\mathrm{TiO}_{2}$ content of the silica-rich subtypes of both plutons is $0.2-0.3 \%$.

The Estonian porphyraceous granites are characterized by relatively low Niggli $\mathrm{mg}$ indices varying from 0.1 to 0.35 , and negative value $t$ $(t=a l-(c+a l k))$ ranging from -1 to -8 . The Niggli main values suggest that the composition of the Estonian granites is close to typical rapakivi granites (Table 4), but value alk of the Estonian granites is systematically lower. 
Significant positive correlation between si and $a l \quad(r=0.76)$ and negative correlation between $a l$ and $f m(r=-0.79)$ and $f m$ and alk ( $r=-0.88$ ) can been observed, weak correlation-of value $c$ versus $s i$, $a l, f m$, and $a l k$, and si versus alk was noticed. Significant correlation between $\mathrm{Si}$ and $\mathrm{K}$ was observed for silica-poor varieties with discriminating point $s i=320-350$. For silica-rich subtypes this correlation is not significant (see Fig. 2).

It can be noted that the silica-poor varieties of the Märjamaa pluton are richer in potassium than their analogues of the Neeme pluton (with the close silica content). There is no correlation between $\mathrm{Na}$ and $\mathrm{K}$; some differences can be observed between the plutons (Fig. 2). The average $\mathrm{Na} / \mathrm{K}$ atomic ratios for the granites of the Taebla, Märjamaa, and Neeme plutons are $0.62,0.75$, and 1 , respectively. The average $\mathrm{Ca} / \mathrm{Na}$ atomic ratios of the two largest plutons, Märjamaa and Neeme, are quite similar: 0.4 and 0.35 , respectively, ranging for other plutons from 0.26 to 0.32 . Fig. 2 shows also the $\mathrm{K} / \mathrm{Rb}$ ratio of Märjamaa and Neeme plutons.

In Figs. $3 a$ and $3 b$, the atomic ratios $\mathrm{Ca} / \mathrm{Ca}+\mathrm{Na}$ and $\mathrm{Mg} / \mathrm{Mg}+\mathrm{Fe}$ of the Märjamaa and Neeme samples plotted versus the silica content display $2-3$ separate trends corresponding possibly to different phases. The atomic ratio $\mathrm{K} / \mathrm{K}+\mathrm{Na}$ cannot be directly used for the discrimination of porphyraceous granites.

\section{Discussion}

Many aspects concerning tectonomagmatic affinities (type of magma, mechanism of magma generation) and emplacement, the crystallization mechanism, etc. of the Estonian porphyraceous granites are still unknown.

Contacts between the porphyraceous granites and the surrounding gneisses are sharp without noticeable contact reactions (on the basis of two contact drill cores). However, in drill core 348 (Taebla pluton), a fresh K-feldspar generation in the surrounding gneisses can be traced.

On the basis of several petrogenetic components and their ratios $(\mathrm{Mg}, \mathrm{Ca}, \mathrm{Fe}, \mathrm{Ti}, \mathrm{Mg} / \mathrm{Mg}+\mathrm{Fe}, \mathrm{Ca} / \mathrm{Ca}+\mathrm{Na})$, the differences between the two best studied plutons, Neeme and Märjamaa, can be observed (see Figs. $3 A$ and $3 B$ ). The present data suggest that Neeme granites are richer in silica and their $\mathrm{Mg} / \mathrm{Ma}+\mathrm{Fe}$ ratio is mostly lower than that of Märjamaa granites.

The Estonian porphyraceous granites show similarities to typical rapakivi granites of the Salmi, Wiborg, and Korosten plutons. The acid rocks of the Salmi pluton, Karelia, form four intrusive phases (see also Figs. $3 A$ and $3 B$; Великославинский et al., 1978). The first and the second phase are represented by olivine-pyroxene-hornblende adamellites and ovoidal hornblende-biotite granites, respectively. Even-grained biotite granites as the third phase and porphyraceous biotite as the fourth phase are known. The Wiborg pluton consists of four main intrusive phases (Великославинский et al., 1978; Vorma, 1976). The rocks of the first intrusive phase are represented by pyroxene-hornblende granites (Lappee-granite) corresponding to adamellites. Ovoidal granites containing biotite and hornblende are interpreted as the second phase and trachytoidic varieties as the third phase. The fourth phase is represented by porphyraceous granites with fine-grained groundmass. Granitic rocks of the Korosten rapakivi granite pluton in the Ukrainian Shield form three intrusive phases (Великославинский et al., 1978). The earliest 
granitic phase is composed of fine-ovoidal hornblende-biotite granites. The coarse-ovoidal hornblende-biotite granites have been distinguished as the second phase and even-grained biotite granites as the third phase.

On the diagram depicting $\mathrm{Mg} / \mathrm{Mg}+\mathrm{Fe}$ versus $\mathrm{SiO}_{2}$, the melanocratic granites of the Märjamaa and Neeme plutons show petrochemical similarities to the first phases of Salmi and Wiborg granites (Fig. 3A, left trend), but they have a lower iron content and they contain also less $\mathrm{Fe}$ and $\mathrm{Mg}$, as expressed by the lower $\mathrm{Mg} / \mathrm{Fe}$ ratio (cf. Великославинский et al., 1978), leucocratic rocks of the Märjamaa and Neeme plutons are closer to the rocks of the second, the third, and the fourth phases of the Wiborg pluton (Fig. $3 A$, central trend).

Somewhat more obvious similarities of the Märjamaa and Neeme plutons and the three above-mentioned rapakivi granitic plutons are displayed in the diagram of $\mathrm{Ca} / \mathrm{Ca}+\mathrm{Na}$ versus $\mathrm{SiO}_{2}$ (Fig. $3 B$ ). Two well differentiated trends with the discriminating point $\mathrm{SiO}_{2}=68-69$ wt \% corresponding to the Märjamaa rocks and three corresponding to the Neeme rocks can be distinguished. However, the rocks corresponding to the first phases of the Wiborg and Salmi plutons show petrochemical characteristics between the Märjamaa (upper trend) and Neeme (lower trend) granites (first trend in Fig. $3 B$ ). Having lower $\mathrm{Ca} / \mathrm{Ca}+\mathrm{Na}$ values, Märjamaa porphyraceous potassium granites corresponding to the central trend are comparable with the second and the third phases of Wiborg granites (the first and the second phase of Korosten granites and the second phase of Salmi granites have somewhat lower $\mathrm{Ca} / \mathrm{Ca}+\mathrm{Na}$ values). Rock samples containing more than 74 wt $\% \mathrm{SiO}_{2}$, typical of Neeme granites, display positive correlation between $\mathrm{SiO}_{2}$ and $\mathrm{Ca} / \mathrm{Ca}+\mathrm{Na}$ (somewhat similar to the first phase, Fig. $3 B$ ). This is different from the main trend of rapakivi granites, characterized mostly by negative correlation. Possibly, this reflects a decrease in the $\mathrm{Na}$ content during the metasomatic alteration or the processes of wall-rock assimilation.

Relying upon the diagrams discussed above and the petrographical studies, we have good ground to suppose that the Märjamaa granite pluton consists of at least two phases, possibly originating from two different primary magmas or one which has evolved in different ways. Analogous acidic-basic differentiation of Neeme granites is not as clearly expressed. In comparison with their Märjamaa analogues, the Neeme granites exhibit smaller chemical fluctuation of petrogenic components and display three variation trends of the interrelations of $\mathrm{Ca}$, $\mathrm{Fe}, \mathrm{Mg}$, and $\mathrm{Na}$, possibly corresponding to their three phases.

\section{Conclusions}

The porphyraceous potassium granites of the Estonian small plutons differ from typical rapakivi granites in their smaller size that reaches only a few dozens of kilometres and the lack of the bodies of gabbroic and anorthositic rocks inside the plutons. Mineralogically, these granites are biotite granites with porphyraceous texture, whereas the melanocratic varieties contain hornblende. The typical rapakivi texture (plagioclasemantled K-feldspar) is very rare. Bipyramidal quartz in groundmass is grey or blueish-grey, not black as is common for the rapakivi granites. The close chemical composition, expressed especially by Niggli main values, geological settings, and similar crystallization age of the Estonian porphyraceous granites and those of the rapakivi formation allow us to consider them as belonging to this formation. 
Within the plutons, two to three petrographically and chemically distinguishable phases have been characterized. Similar behaviour of some petrogenic components, such as $\mathrm{Mg}, \mathrm{Fe}$, and especially $\mathrm{Ca}$ and $\mathrm{Na}$ of the Estonian porphyraceous granites and the rapakivi granites of Wiborg, Salmi, and Korosteni, CIS, rapakivi granite plutons can be observed.

Acknowledgements. We are indebted to several geologists of the Geological Survey of Estonia, especially to K. Suuroja, for giving us permission to use some geological material and chemical analyses made in their laboratory. We thank our colleague Dr. Vello Klein for his constructive remarks on the manuscript and also Mr. Ivar Puura who made useful comments and improved our English.

\section{REFERENCES}

Kirs, J., Huhma, H. and Haapala, I. 1991. Petrological-chemical features and age of Estonian postorogenic potassium granites. - In: Symposium on Rapakivi granites and related rocks. Abstract. 28-29.

Klein, V., Konsa, M. and Niin, M. (in prep.). On the mineralogy of porphyraceous potassium granitoids of Estonia.

Lundquist, T. 1968. Precambrian geology of the Loos-Hamra region, Central Sweden. S.G.U. Ser. Ba, 23.

Rämö, T. 1991. Petrogenesis of the Proterozoic rapakivi granites and related basic rocks of southeastern Fennoscandia: $\mathrm{Nb}$ and $\mathrm{Pb}$ isotopic and general geochemical constraints. - Geol. Surv. of Finland, Bull. 355, 161.

Vaasjoki, M. 1977. Rapakivi granites and other postorogenic rocks in Finland: their age and the lead isotopic composition of certain associated mineralizations. Geol. Surv. of Finland, Bull. 294.

Vorma, A. 1976 . On the petrochemistry of rapakivi granites with special reference to the Laitila pluton, southwestern Finland. - Geol. Surv. of Finland, Bull. 285.

Welin, E., Lundqvist, T. 1970. New Rb-Sr age data for the Sub-Jotnian voleanics (Dala porphyries) in the Loos-Hamra region, Central Sweden. - G. F. F. 1970 Col. $92,540,35-39$.

Великославинский Д. А., Биркис А. П., Богатиков О. А., Бухарев В. П., Великославинский С. Д., Гордиенко П. И., Зинченко О. В., Кивисилла Я. Я., Кирс Ю. Э., Кононов Ю. В., Певицкий Ю. Ф., Нийн М. Н., Пуура В. А., Хворов М. В., Шустова П. Е. 1978. Анортозит-рапакивигранитная формация, Восточно-Европейская платформа. Ленинград, Наука.

Кирс Ю., Пуура В., Биркис А., Кивисилла Я., Клейн В., Мотуза Г., Нийн М., Суурor K. 1990. Новые данные о магматических комплексах фундамента Прибалтики. - In: Геология и геохронология докембрия Восточно-Европейской платформы. Ленинград, Наука, 155-166.

Кууспалу T. 1971. Зональный кварц из гранитов рапакиви Эстонии. - Изв. АН ЭССР. Хим. Геол., 20, 1, 43-47.

Кууспалу T. 1975. Граниты рапакиви кристаллического фундамента Эстонии. - Уч. зап. ТГУ, вып. 359. Тр. по геологии, 76-142.

Побул Э. 1962. О строении кристаллического фундамента Эстонии по данным геофизики. - In: Геология палеозоя. Таллинн, 309-318.

Побул Э., Вахер Р., Арвисто Э. 1968. Физические свойства пород кристаллического фундамента Эстонии. - Изв. АН ЭССР. Хим. Геол., 17, 4, 393-408.

Пуура В. 1974. К-Аг изотопный возраст пород кристаллического фундамента Северной Прибалтики, - Изв. АН ЭССР. Хим. Геол., 23, 1, 40-49.

Пуура В., Мурима Г., Миркина С. 1974. Возраст порфоровидных гранитов рапакиви Северной Эстонии по данным стронциевого и свинцового методов. Изв. АН ЭССР. Хим. Геол., 23, 2, 169-171.

Пуура В., Вахер Р. М., Клейн В. М., Коппельмаа Х. Я., Нийн М. Н., Ванамб В. В., Кирс Ю. Э. 1983. Кристаллический фундамент Эстонии. Москва, Наука.

Эскола П. 1967. Докембрий Финляндии. - In: Докембрий Скандинавии. Москва, Мир, 154-261. 


\section{EESTI EELKAMBRIUMI PORFUURILAADSETE KAALIUMGRANIITIDE PETROGRAAFIAST JA PETROKEEMIAST}

Eesti aluskorras on teada viis intrusiivse iseloomuga varaplatvormset porfüürilaadset kaaliumgraniidi (PKG) massiivi: Märjamaa, Neeme, Naissaare, Ereda ja Taebla. Peamised kivimit moodustavad mineraalid on mikrokliin, kvarts, plagioklass ja biotiit, melanokraatsetel erimitel ka küünekivi. Lisandmineraalidena on teada apatiit, fluo. riit, tsirkoon, sfeen, muskoviit jt. Eesti $\mathrm{PKG}$ keemiline koostis on üsna lähedane tüüpilisele rapakivi graniidile, erinedes viimasest mōneti suurema titaani ja väiksema summaarse raua ja alumiiniumi sisalduse poolest. Ka mitmed geoloogilis-struktuursed iseärasused (kuju, varaplatvormsed tingimused jt.) lubavad nimetatud massiivide kivimeid võrrelda rapakivi graniitidega. Petrograafiliselt, samuti keemilise koostise põhjal on eristatavad $2-3$ intrusiivset faasi. $\mathrm{Mg} / \mathrm{Mg}+\mathrm{Fe}-\mathrm{SiO}_{2}$ ja $\mathrm{Ca} / \mathrm{Ca}+\mathrm{Na}-\mathrm{SiO}_{2}$ diagrammidel moodustavad Märjamaa ja Neeme massiivide PKG-d kolm eraldi trendi, mis on võrreldavad mitmete rapakivi graniitide vastavate suurustega eraldi faaside kaupa.

\section{Aлвар COECOO, Мати НИйН}

\section{ПЕТРОГРАФИЧЕСКИЕ И ПЕТРОХИМИЧЕСКИЕ ЧЕРТЫ ДОКЕМБРИЯСКИХ ПОРФИРОВИДНЫХ КАЛИЕВЫХ ГРАНИТОВ ЭСТОНИИ}

Описаны пять раннеплатформенных интрузивных массивов порфнровидных калиевых гранитов фундамента Эстонии: Мярьямааский, Неэмеский, Таэблаский, Найссаареский и Эредаскнй. Основные минералы названных гранитов: микроклин, кварц, плагиоклаз, бнотит, для меланократовых разновндностей характерна и роговая обманка. Второстепенные минералы представлены апатнтом, флюоритом, цирконом, сфеном, мусковнтом и др. По хнмнческому составу порфировндные калиевые граниты Эстонии довольно близки к типичным гранитам рапакнви, хотя отличаются от них повышенным содержанием титана и пониженным содержаннем железа и глинозема. Состав, а также некоторые геолого-структурные черты позволяют сравнивать описанные граниты с типичными гранитамн рапакиви. Петрографически и петрохимнчески выделяются 2-3 фазы. На диаграммах $\mathrm{Mg} / \mathrm{Mg}+\mathrm{Fe}-\mathrm{SiO}_{2}$ и $\mathrm{Ca} / \mathrm{Ca}+\mathrm{Na}-\mathrm{SiO}_{2}$ образуются 2 -3 отдельных тренда, которые, вероятно, отвечают разным фазам интрузии некоторых гранитов рапакиви. 